\title{
MicroRNA-17-92 significantly enhances radioresistance in human mantle cell lymphoma cells
}

\author{
Ping Jiang ${ }^{1}$, En Y Rao' ${ }^{2}$ Na Meng ${ }^{1}$, Yong Zhao ${ }^{2}$, Jun J Wang ${ }^{*}$
}

\begin{abstract}
The microRNA-17-92 (miRNA-17-92) cluster, at chromosome 13q31-q32, also known as oncomir-1, consists of seven miRNAs that are transcribed as a polycistronic unit. Over-expression of miRNA-17-92 has been observed in lymphomas and other solid tumors. Whether miRNA-17-92 expression affects the response of tumor cells to radiotherapy is not addressed so far. In the present study, we studied the effects of miRNA-17-92 on the radiosensitivity of human mantle cell lymphoma (MCL) cells Z138c. Over-expression of miRNA-17-92 significantly increased survival cell number, cell proliferation and decreased cell death of human MCL cells after different doses of radiation. Immunoblot analysis showed that phosphatase and tension homolog (PTEN) and PHLPP2 was downmodulated and pAkt activity was enhanced in MCL cells after over-expressing miRNA-17-92 after irradiation. These findings are the first direct evidence that over-expression of miRNA-17-92 cluster significantly increases the radioresistance of human $\mathrm{MCL}$ cells, which offers a novel target molecule for improving the radiotherapy of $\mathrm{MCL}$ in clinic.
\end{abstract}

\section{Introduction}

The importance of microRNAs in cancer is highlighted by the observation that approximately $50 \%$ of miRNA genes are located in cancer-associated genomic regions or in fragile sites [1,2], which are frequently amplified or deleted in tumorigenesis. Mantle cell lymphoma (MCL) is an aggressive hematological malignancy, characterized by the chromosomal translocation $\mathrm{t}(11 ; 14)(\mathrm{q} 13 ; \mathrm{q} 32)$, which results in deregulated aberrant expression of cyclin D1, and comprises $5 \%-10 \%$ of human B-cell malignancies [3]. The median survival of patients with MCL ranges between 3 and 5 years according to most studies $[4,5]$. Studies in transgenic mice imply that the $\mathrm{t}(11 ; 14)(\mathrm{q} 13$; q32) translocation alone is not sufficient to result in lymphoma, and additional genetic alterations are necessary $[6,7]$. Secondary genomic alterations are frequently detected in MCL, of which chromosome 13q31-q32 gain/ amplification is one of the most frequent $[8,9]$. Studies have shown that amplification at chromosome 13q31q32 targets a microRNA cluster, microRNA-17-92

\footnotetext{
* Correspondence: doctorwangjunjie@yahoo.com.cn

'Department of Radiation Oncology, Peking University Third Hospital, Beijing 100191, China

Full list of author information is available at the end of the article
}

(miRNA-17-92), which resides within intron 3 of c13orf25, a non-protein-coding gene at 13q31.3 [10,11].

The miRNA-17-92 cluster, which modulates E2F1 expression, is positively regulated by $\mathrm{MyC}$ [12], can potentially become a very potent oncogene, targeting multiple cellular pathways and favoring tumorigenesis by enhancing cell proliferation and inhibiting apoptosis. Previous data have shown that miRNA-17-92 can increase MyC-enhanced proliferation by targeting $\mathrm{p} 21$ and consequently activating the cyclinD1/CDK4 complex to release retinoblastoma inhibition of E2F genes [13,14]. miRNA17-92 is also capable of minimizing MyC-induced apoptosis by targeting the Bcl2-like Bim and phosphatase and tension homolog (PTEN) genes [15] to increase the level of anti-apoptotic BCL2.

Radiation therapy is one of the three primary modalities used in cancer treatment. Whether miRNA-17-92 expression affects the response of tumor cells to radiotherapy has not been investigated so far. To elucidate this issue, we generated stable MCL cell lines with high expression of the miRNA-17-92 cluster and the radiosensitivity was determined. We found that over-expression of miRNA-17-92 in MCL cells remarkably decreases the radiosensitivity of the MCL cell line $\mathrm{Z138c}$ while the 
activity of PI3K/Akt pathway is enhanced possibly via down-regulation of PTEN and PHLPP2. We thus offered first evidence that miRNA17-92 is closely involved in the radioresistance of tumor cells.

\section{Materials and methods}

\section{Plasmid, cell lines and cell transfection}

The tetracyclin-regulated retroviral vector TMP (OpenBioSystem, Huntsville, AL) was modified by deleting the miR-30 sequence using PCR with the following primers: 5'-PO4-GCCTCGAGCCTGAGGCTGGATCGGTCC CGGTGTCTTCTATGG-3', and 5'-PO4-TGAGGGAAT TCGGACCGGGTAGGGGAGGCGCTTTTCCCAAG-3'.

The PCR product was then circularized by blunt-end ligation to generate the miRNA-17-92 cluster was amplified from human genomic DNA using the following primers: 5'-tttttctcgaGTGTCTAAATGGACCTCATATC TTTGAG-3', and 5'-gtttttgaattCCAAATCTGACACGCAACCC-3' (antisense) and Phusion Taq Polymerase (New England Biolabs, Boston, MA). The PCR product was then cloned into the TMP2 vector to generate the plasmid TMP2-miR-17-92. Vector TMP2 and plasmid TMP2-miR-17-92 were kindly provided by Dr En Y Rao who was in Institute of Zoology, Chinese Academy of Sciences. To construct 3'untranslated region (UTR) luciferase reporter plasmids, the pGL3 vector with luciferase coding sequence purchased from Promega company, USA.

The expression level of mature miRNAs was determined using the TaqMan miRNA Assay (Applied Biosystems, Foster City, CA) with slight modification. Briefly, single-stranded cDNA was synthesized from $10 \mathrm{ng}$ of total RNA using the TaqMan MicroRNA Reverse Transcription Kit. Each cDNA generated was amplified by quantitative PCR using sequence-specific primers from the TaqMan MicroRNA Assays (Human Panel) on a 7900 HT Sequence Detection System. The relative quantity of the target miRNAs was estimated by the $2^{-\Delta \Delta C T}$ method by normalizing to the expression level of $\beta$-actin, which was detected by a TaqMan gene expression Assay.

Human mantle cell lymphoma (MCL) cell line Z138c was provided by institute of zoology, Chinese Academy of Sciences.

Tetracycline-regulated pRevTet-On expression system purchased from Clontech, USA, operated according to the manufacturer's instructions. The human embryonic kidney cell line HEK293T was co-transfected with the pRevTet-On vector and $\mathrm{pCL}$ packaging plasmid using the calcium phosphate method. The virus supernatant was collected and used to infect Z138c. The transfected cell line Z138c-Tet-On was selected with G418 (1 $\mu \mathrm{g} /$ $\mathrm{ml}$ ) which purchased from Sigma company USA. To further establish TMP2-miR17-92 cell line, the HEK293T cell line was co-transfected with the TMP2-
miR-17-92 vector and $\mathrm{pCL}$ packaging plasmid by the calcium phosphate method, and the virus supernatant was collected and used to transfect the established Z138c-Tet-on cells. These cells were further selected with puromycin resistance and green fluorescent protein (GFP) expressing cells were isolated by fluorescence activated cell sorter, (FACS). The cell lines which overexpress miR-17-92 were maintained in the presence of doxycycline $(1 \mu \mathrm{g} / \mathrm{ml})$.

The HEK293T cell line was co-transfected with the TMP2 vector and PCL packaging plasmid by the calcium phosphate method, and the virus supernatant was collected and used to infect the established Z138c-Teton cells. And then Z138c-TMP2 cell line was generated.

\section{Cell culture}

The Z138c-miRNA-17-92 cell lines and Z138c-TMP2 cell lines were suspended in RPMI1640 supplemented with $10 \%$ fetal bovine serum (FBS), $100 \mathrm{UI} / \mathrm{ml}$ penicillin, and $100 \mathrm{UI} / \mathrm{ml}$ streptomycin. Doxycycline $(1 \mu \mathrm{g} / \mathrm{ml})$ was added to induce the expression of miRNA-17-92. The cells were incubated in a humidified atmosphere of $5 \% \mathrm{CO}_{2}$ at $37^{\circ}$.

\section{Irradiation conditions}

Linear accelerators producing $6 \mathrm{MV} \mathrm{X}$-ray beams were provided by the 306 Hospital of the People's Liberation Army (Beijing, China). The dose rate was $400 \mathrm{cGy} / \mathrm{min}$ and the source-to-skin distance (SSD) was $100 \mathrm{~cm}$. The surface of the culture dishes was covered by $2 \mathrm{~cm}$ of packing materials. Radiation doses were: $0,0.5,1,2,3,4$ and $6 \mathrm{~Gy}$.

\section{Viable cell count}

Z138c-TMP2 and Z138c-TMP2-miRNA-17-92 cells in exponential growth were irradiated by $6 \mathrm{MV} \mathrm{X}$-ray at various doses $(0,0.5,1,2,3,4$, and 5 Gy). Three wells in each dose in 24 well plates were cultured for 24, 48, 72 or $96 \mathrm{~h}$ in an incubator, cells were stained with trypan blue for the viable count estimation.

\section{Cell proliferation measured by ${ }^{3} \mathrm{H}-\mathrm{TdR}$ incorporation}

Z138c-TMP2 and Z138c-miRNA-17-92 cells in exponential growth were irradiated by $6 \mathrm{MV} \mathrm{X}$-ray at various doses $(0,0.5,1,2,3,4,5$, and 6 Gy). Cells were plated in 96-well plates in $200 \mu \mathrm{l}$ of growth medium and allowed to attach for $12,36,60,84$ or $112 \mathrm{~h}$, and 0.5 $\mu \mathrm{Ci}{ }^{3} \mathrm{H}$-TdR per well was added respectively, then incubated for $12 \mathrm{~h}$ at $37^{\circ}$. After incubation the cells were collected and distributed through a glass fiber filter by using a multiple head cell harvester type DYQ-II. When the filter membrane was dry, the corresponding membranes were cut off and put into $5 \mathrm{ml}$ of scintillation solution to be detected. 
Cell cycle analysis by flow cytometry (FCM)

Z138c-TMP2 and Z138c-miRNA-17-92 cells in exponential growth were irradiated by $6 \mathrm{MV} \mathrm{X}$-ray at various doses (0, 2, and 4 Gy). $24 \mathrm{~h}$ after irradiation, cell cycle was analyzed using FCM as described previously.

Z138c-TMP2 and Z138c-TMP2-miRNA-17-92 cells in exponential growth were irradiated by $6 \mathrm{MV} \mathrm{X}$ ray at various doses (0,2, and $4 \mathrm{~Gy}) .24 \mathrm{~h}$ after irradiation, $2 \times 10^{6}$ cells were taken from each sample to be tested, which were fixed by $3 \mathrm{ml} 70 \%$ alcohol at $-20^{\circ}$ over night. Then washed by PBS twice and suspended in $200 \mathrm{ul}$ PBS, placed in $37^{\circ}$ water for $30 \mathrm{~min}$, mixed with $10 \mathrm{mg} / \mathrm{ml}$ RNA enzyme and $500 \mu \mathrm{g} / \mathrm{ml}$ PI, waiting to be tested.

\section{Apoptosis and necrosis analysis by FCM}

Z138c-TMP2 and Z138c-TMP2-miRNA-17-92 cells in exponential growth were irradiated by $6 \mathrm{MV} \mathrm{X}$ ray at various doses ( 0,2 , and 4 Gy, respectively). 72 hours later, cells were plated in 24-well plates and $1 \mathrm{ml} 1 \%$ Hochest33324 per well was added respectively, taken photo after 30 40 min.

Z138c-TMP2 and Z138c-TMP2-miRNA-17-92 cells in exponential growth were irradiated by $6 \mathrm{MV} X$ ray at various doses (0, 2, and $4 \mathrm{~Gy}$, respectively). 72, 96, 120 hours after irradiation, the cells were stained by Propidium iodide (PI) to detect the percent of cell death.

\section{Immunoblotting and antibodies}

Cell lysates containing $20 \mu \mathrm{g}$ of protein were resolved on sodium dodecyl-sulfate polyacrylamide gel electrophoresis (SDS-PAGE) and transferred to nitrocellulose membranes (Hybond-P, Amersham, Buckinghamshire, UK). The membranes were incubated with $5 \%$ non-fat milk blocking buffer (TBS-T) for $1 \mathrm{~h}$ at room temperature and then incubated overnight at $4^{\circ} \mathrm{C}$ with the primary antibodies. Membranes were washed with PBS containing $0.1 \%$ Tween-20 (PBS-T), then incubated in the dark for $1 \mathrm{~h}$ at room temperature with IRDye 680conjugated goat anti-rabbit IgG or IRDye 800 conjugated goat anti-mouse IgG in Odyssey blocking buffer. After washing with PBS-T, proteins were detected and quantified using the Odyssey Infrared Imaging System (LI-COR Biosciences). For each study, data were representative of three independent experiments.

Antibodies for immunoblotting in this study were as follows: anti-PTEN, anti-Akt, anti-p-Akt-ser473 (Cell Signaling Biotechnology, Beverly, MA, USA), anti-goat IgG-HRP, anti-actin, and anti-PH domain leucine-rich repeat protein phosphatase (PHLPP) (Novus Biologicals, Littleton, CO, USA).

\section{Statistical analysis}

All data have been presented as the mean \pm s.d. Student's unpaired t-test for comparison of means has been used to compare groups. A P-value 0.05 has been considered to be statistically significant.

\section{Results}

The over-expression of miRNA-17-92 significantly enhanced survival of $Z 138 \mathrm{c}$ cells after different doses of radiation

In order to determine whether over-expression of miRNA-17-92 could change the survival of Z138c cells after ionizing irradiation, we counted the viable cells after different doses of irradiation and at different time points. As shown in Figure 1, there were no differences between the two groups in viable Z138c-TMP2 or Z138c-miRNA-17-92 cell counts without radiation. However, viable cell counts were significantly higher in the miRNA-17-92 group than in the TMP2 group when these cells received different doses of irradiation by 1 day after irradiation $(\mathrm{P}<0.05, \mathrm{P}<0.01$, and $\mathrm{P}<$ 0.001 , respectively, Figure 1 ).

\section{The different proliferative ability of Z138c-TMP2 and} Z138c-miRNA-17-92 cells after different doses of radiation To investigate the effect of miRNA-17-92 on the proliferating ability of tumor cells, we detected the cell proliferation of Z138c cells expressing miRNA17-92 or control vector after irradiation using a ${ }^{3} \mathrm{H}-\mathrm{TdR}$ incorporation assay. There were no difference between the two groups after radiation at 0 Gy (Figure 2). However, statistically significant differences were obtained at a radiation dose of $2 \mathrm{~Gy}$ and incubation times of 48, 72, 96 , and $120 \mathrm{~h}$ and at a radiation dose of 4 Gy and incubation times of 24, $48 \mathrm{~h}, 72,96$, and $120 \mathrm{~h}(\mathrm{P}<0.05$, $\mathrm{P}<0.01$ or $\mathrm{P}<0.001$, Figure 2 ).

\section{The cell cycle distribution of Z138c-TMP2 and Z138c-} miRNA-17-92s cells after different doses of radiation

The cell cycle was determined by PI staining and assayed by FCM. The percentage of G2/M cells in the Z138cTMP2 cells increased after radiation doses of 2 Gy and 4 Gy comparing with the non-irradiated cells (Figure 3). However, no obvious radiation-induced G2/M cell cycle arrest was observed in Z138c-miRNA-17-92 cells. A statistically significant difference $(\mathrm{t}=2.885, \mathrm{P}<0.05)$ was obtained at a radiation dose of 4 Gy compared between Z138c-TMP2 and Z138c-miRNA-17-92 cells.

\section{The cell death of Z138c-TMP2 and Z138c-miRNA-17-92s cells after different doses of radiation}

The cell death ratio was evaluated using traditional PI staining assay. As shown in Figure 4, more dead cells were seen in the Z138-TMP2 cells than in Z138cmiRNA-17-92 cells at 72, 96, and $120 \mathrm{~h}$ after radiation, regardless of radiation doses, respectively. Statistically significant differences were observed at a radiation dose 


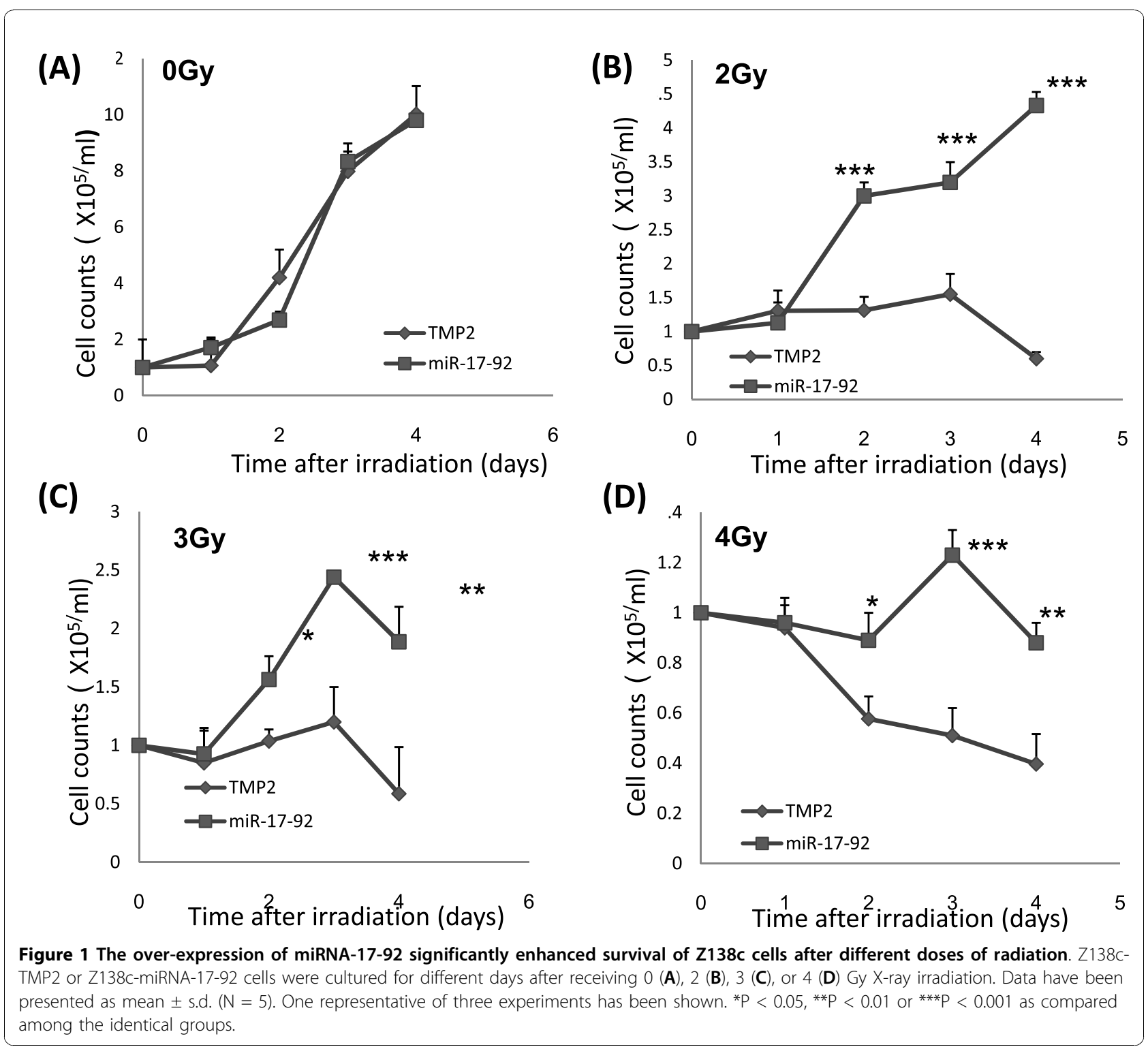

of 2 Gy and incubation times of 96 , or $120 \mathrm{~h}$ and at a radiation dose of $4 \mathrm{~Gy}$ and incubation times of 96 or $120 \mathrm{~h}(\mathrm{P}<0.05, \mathrm{P}<0.01$ or $\mathrm{P}<0.001$, respectively, Figure 4).

The expression of the proteins pAkt, PTEN and PHLPP2 in Z138c-TMP2 and Z138c-miRNA-17-92 cells after radiation As PTEN and PHLPP2 are the target genes of miRNA17-92, we thus examined the protein expression of pAkt, PTEN and PHLPP2 in both cell lines by immunoblot analysis after radiation. As shown in Figure 5, compared with Z138c control cells, PTEN and PHLPP2 protein levels were reduced in Z138c-miRNA-17-92 cells after radiation. Consistently, pAkt was enhanced in Z138c-miRNA-17-92 cells after radiation.

\section{Discussion}

MCL is considered incurable with the current chemotherapeutic regimen. Gene expression profiling (GEP) studies have shown that the survival of MCL patients is closely correlated with the proliferation signature of the tumor cells [16]. It is interesting that over-expression of c13orf25, the primary transcript from which miRNA-1792 is processed, has been associated with increased expression of genes associated with proliferation and poorer survival. Since this observation is based on GEP analysis, further large-scale, confirmatory, clinical studies using more specific approaches are warranted. In the present study, we demonstrated that over-expression of miRNA17-92 in tumor cells can significantly enhance the resistance to radiation-induced cell damage including cell 


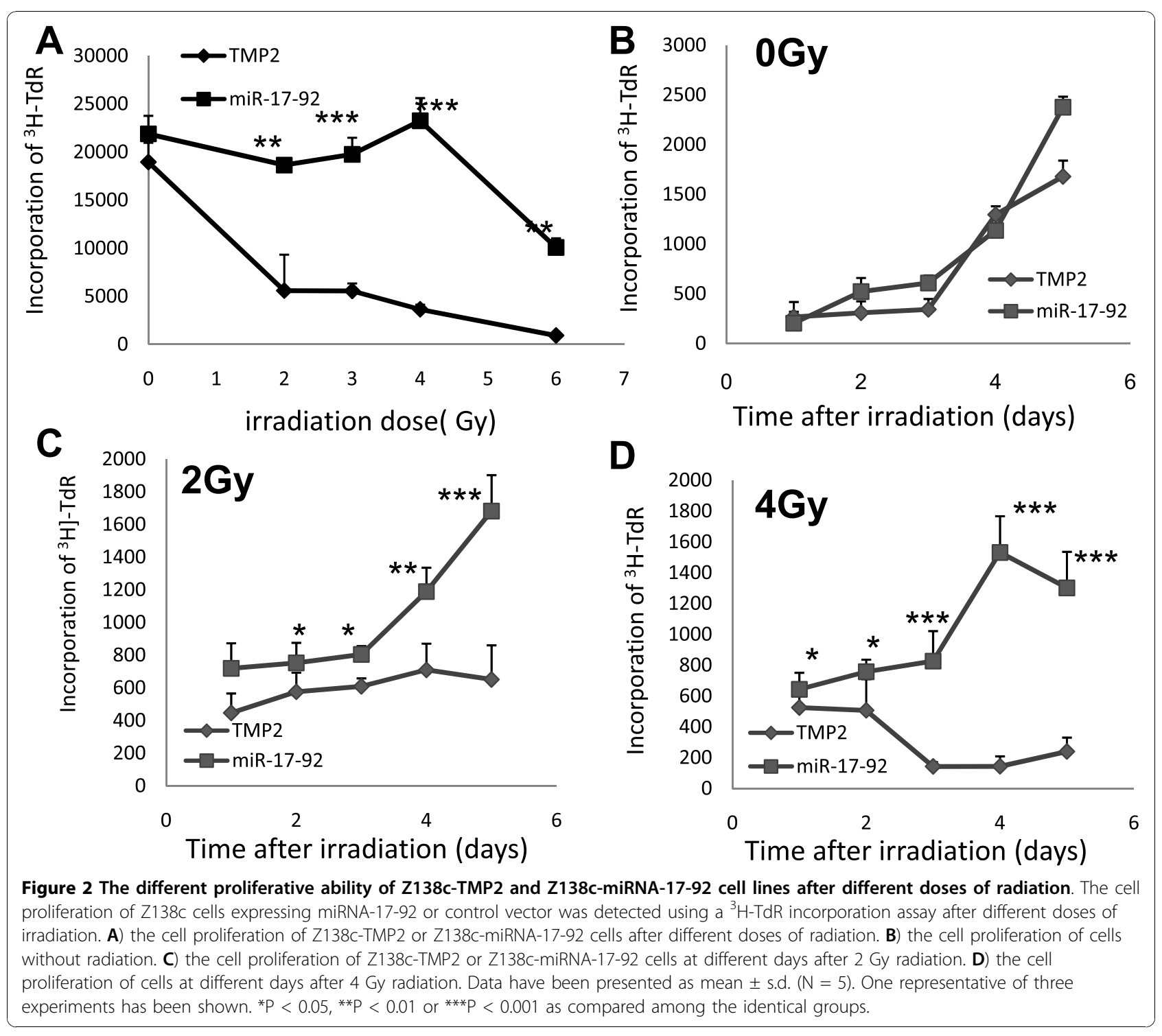

death and G2/M phase arrest. Our findings suggest that targeting the miRNA-17-92 cluster may provide a novel therapeutic approach for MCL patients. It may be important for us to see whether the expression of this cluster is closely relevant to the radiation sensitivity or not in the clinical cases in the future.

PTEN is a lipid phosphatase that removes the activating signal and ultimately prevents Akt phosphorylation and activation, while PHLPP2 terminates Akt signaling by directly dephosphorylating and inactivating Akt, thus, both pTEN and PHLLP2 negatively regulates PI3K/Akt signaling pathway, which is one of the most important pathways for cell survival and inhibition of apoptosis [17-20]. Deletion of the chromosome 10 PTEN gene plays a role in tumor suppression. After
$\mathrm{X}$-ray radiation, Z138c cells with over-expression of miRNA-17-92 showed down-modulated tumor suppressors PTEN and PHLPP2 and enhanced pAkT as determined by western blot. Ramaswamy et al [21] showed that suppression of the PTEN/PI3K/AKT signaling pathway may increase the radiosensitivity of malignant brain neurogliocytoma cells. Our present study showed that over-expression of miRNA-17-92 decreased both PTEN and PHLPP expression and thereby enhanced PI3K pathway and finally results in cell death resistance induced by $\mathrm{x}$-rays. Because of the complexity of miRNA-17-92 function, more targets may exist for regulating the cell transduction signal by miRNA-17-92 through various modes, which will be a future goal of our research. 
A (a) Control

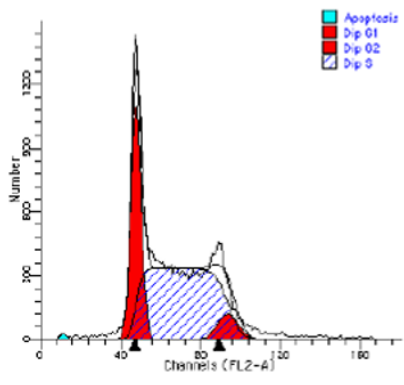

OGy
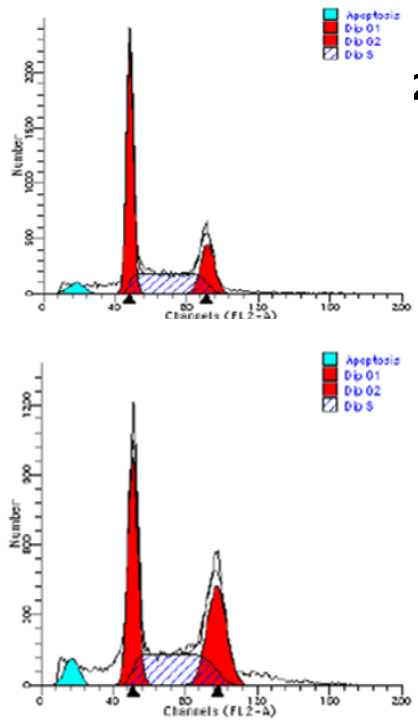

(b) miRNA-17-92

B
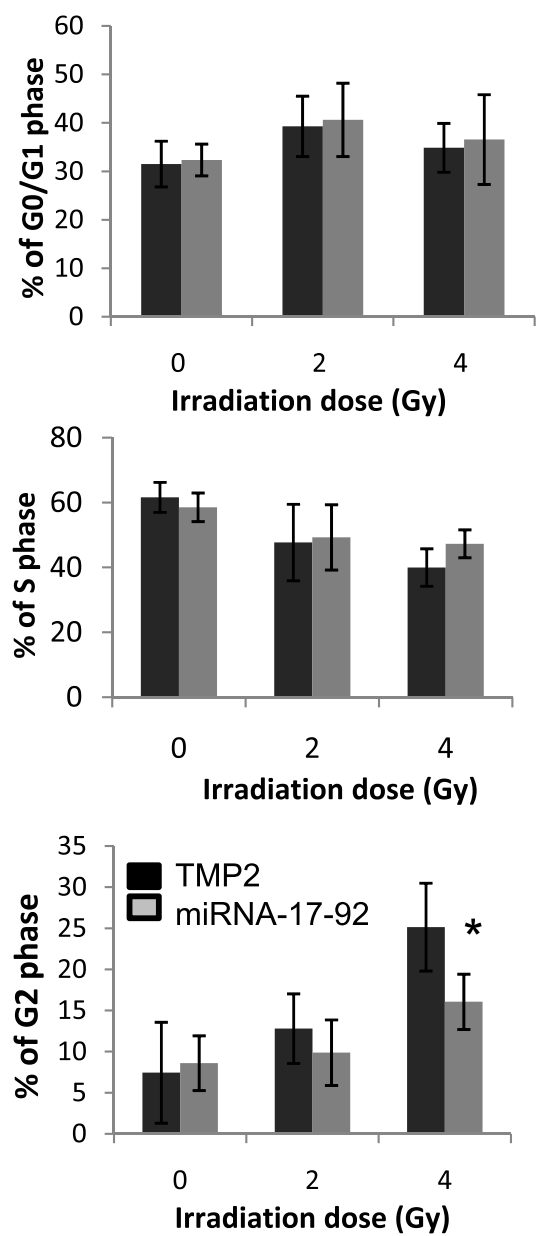

Figure 3 The cell cycle distribution of Z138c-TMP2 and Z138c-miRNA-17-92 cells after different doses of radiation. The cell cycle of Z138c-TMP2 and Z138c-miRNA-17-92 cells was determined by PI staining and detected by FCM at 1 day after radiation. A) one representative of cell cycle distribution as detected by FCM. B) a summary of different cell phases of Z138c-TMP2 and Z138c-miRNA-17-92 cell lines. Data have been presented as mean \pm s.d. $(N=5)$. One representative of three experiments has been shown. ${ }^{*} P<0.05$ as compared among the identical groups.

In a summary, miRNA-17-92 is closely involved in the regulation of radiosensitivity of tumor cells. It directly down-regulates the expression of the PTEN and PHLPP2 proteins, subsequently activates the PI3K/Akt signal pathway, and thus results in the resistance to radiation of the MCL Z138c cell line. MiRNA-17-92 may be a potential molecular target for improving the radiotherapy.

\section{Acknowledgements}

The authors wish to thank Ms. Jing Wang and Ms. Jian X Peng for their expert technical assistance, Ms. Qing H Li for her excellent laboratory management. This work was supported by a grant from the Ministry of Civil Affair, China ([2007]8).

\section{Author details}

${ }^{1}$ Department of Radiation Oncology, Peking University Third Hospital, Beijing 100191, China. ${ }^{2}$ Transplantation Biology Research Division, State Key Laboratory of Biomembrane and Membrane Biotechnology, Institute of Zoology, Chinese Academy of Sciences, Beijing 100101, China.

\section{Authors' contributions}

PJ carried out cell colony-forming assay, fluorescence-activated cell sorting, flow cytometric analysis, and drafted the manuscript. JJW participated in its design and revised the manuscript. NM performed the statistical analysis and carried out the irradiation experiment. YZ and EYR supervised experimental work and revised the manuscript. All authors read and approved the final manuscript. 

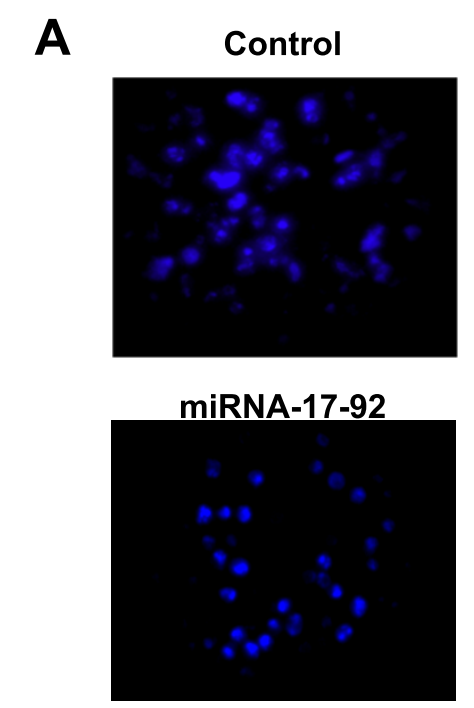

OGy

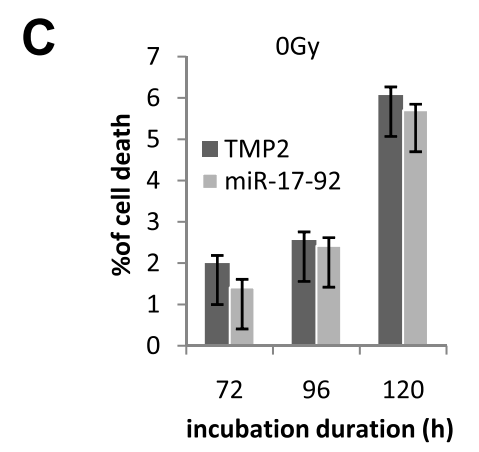

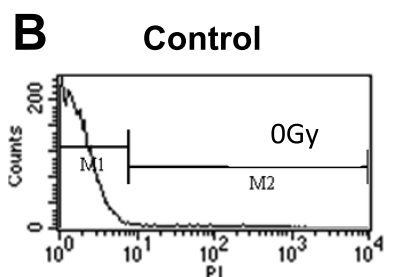
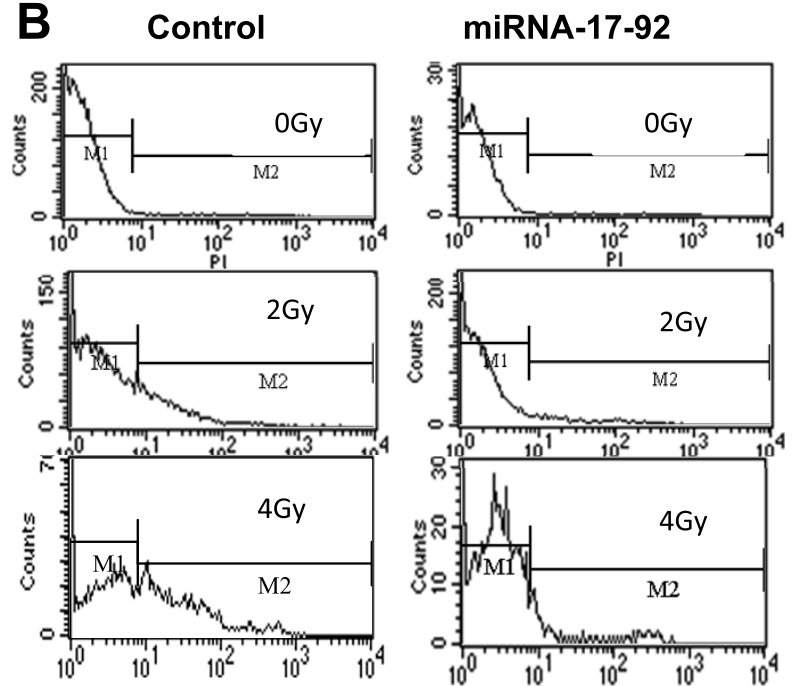

$2 \mathrm{~Gy}$

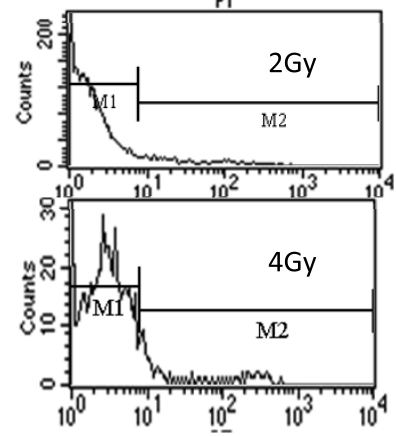

4Gy

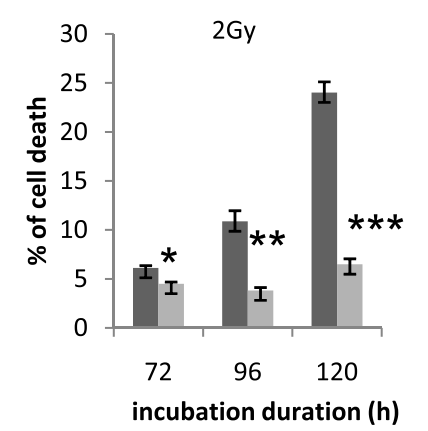

Figure 4 The cell death of Z138c-TMP2 and Z138c-miRNA-17-92s after different doses of radiation. The cell death ratios of Z138c-TMP2 cells and Z138c-miRNA-17-92 cells were evaluated using traditional PI staining assay. A) one representative of cell death as detected by $1 \%$ Hochest33324 staining at 3 days after radiation. B) one representative of cell death as detected by FCM at 3 days after radiation. C) a summary of cell death ratios in Z138c-TMP2 and Z138c-miRNA-17-92 cells. Data have been presented as mean \pm s.d. $(\mathrm{N}=5)$. One representative of three experiments has been shown. ${ }^{*} P<0.05,{ }^{*} P<0.01$ or ${ }^{* *} \mathrm{P}<0.001$ as compared among the identical groups.

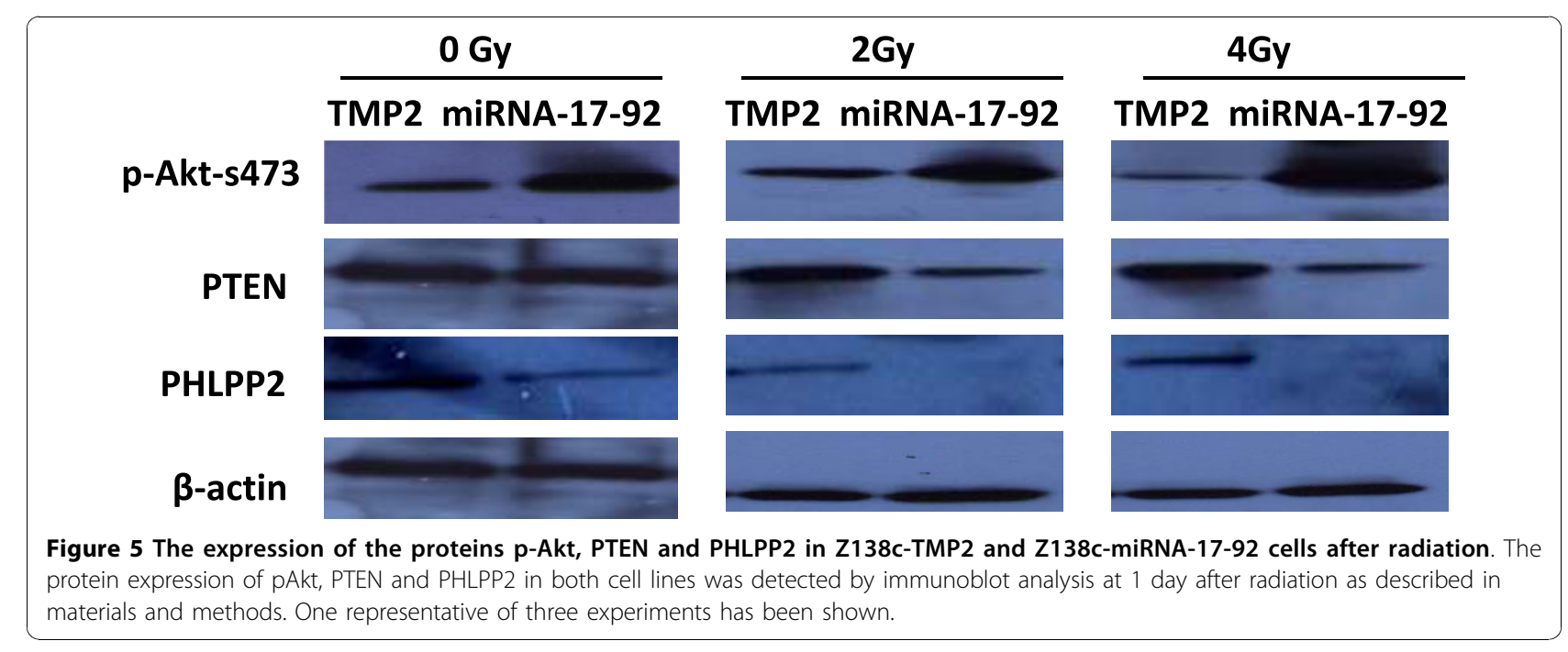




\section{Competing interests}

The authors declare that they have no competing interests.

Received: 21 August 2010 Accepted: 1 November 2010

Published: 1 November 2010

\section{References}

1. Calin GA, Sevignani C, Dumitru CD, Hyslop T, Noch E, Yendamuri S, Shimizu M, Rattan S, Bullrich F, Negrini M, Croce CM: Human microRNA genes are frequently located at fragile sites and genomic regions involved in cancers. Proc Natl Acad Sci USA 2004, 101:2999-3004.

2. Sevignani C, Calin GA, Siracusa LD, Croce CM: Mammalian microRNAs: a small world for fine-tuning gene expression. Mamm Genome 2006, 17:189-202.

3. Jaffe ES: Anaplastic large cell lymphoma: the shifting sands of diagnostic hematopathology. Mod Pathol 2001, 14:219-228.

4. Bosch F, Lopez-Guillermo A, Campo E, Ribera JM, Conde E, Piris MA, Vallespi T, Woessner S, Montserrat E: Mantle cell lymphoma: presenting features, response to therapy, and prognostic factors. Cancer 1998, 82:567-575.

5. Argatoff $L H$, Connors JM, Klasa RJ, Horsman DE, Gascoyne RD: Mantle cell lymphoma: a clinicopathologic study of 80 cases. Blood 1997, 89:2067-2078.

6. Bodrug SE, Warner BJ, Bath ML, Lindeman GJ, Harris AW, Adams JM: Cyclin D1 transgene impedes lymphocyte maturation and collaborates in lymphomagenesis with the myc gene. EMBO J 1994, 13:2124-2130.

7. Lovec H, Grzeschiczek A, Kowalski MB, Moroy T: Cyclin D1/bcl-1 cooperates with myc genes in the generation of B-cell lymphoma in transgenic mice. EMBO J 1994, 13:3487-3495.

8. Wlodarska I, Pittaluga S, Hagemeijer A, De Wolf-Peeters C, Van Den Berghe H: Secondary chromosome changes in mantle cell lymphoma. Haematologica 1999, 84:594-599.

9. Salaverria I, Zettl A, Bea S, Moreno V, Valls J, Hartmann E, Ott G, Wright G, Lopez-Guillermo A, Chan WC, Weisenburger DD, Gascoyne RD, Grogan TM, Delabie J, Jaffe ES, Montserrat E, Muller-Hermelink HK, Staudt LM, Rosenwald A, Campo E: Specific secondary genetic alterations in mantle cell lymphoma provide prognostic information independent of the gene expression-based proliferation signature. J Clin Oncol 2007, 25:1216-1222.

10. Ota A, Tagawa H, Karnan S, Tsuzuki S, Karpas A, Kira S, Yoshida Y, Seto M: Identification and characterization of a novel gene, C13orf25, as a target for 13q31-q32 amplification in malignant lymphoma. Cancer Res 2004, 64:3087-3095

11. He L, Thomson JM, Hemann MT, Hernando-Monge E, Mu D, Goodson S, Powers S, Cordon-Cardo C, Lowe SW, Hannon GJ, Hammond SM: A microRNA polycistron as a potential human oncogene. Nature 2005, 435:828-833.

12. O'Donnell KA, Wentzel EA, Zeller Kl, Dang CV, Mendell JT: c-Myc-regulated microRNAs modulate E2F1 expression. Nature 2005, 435:839-843.

13. Fontana L, Fiori ME, Albini S, Cifaldi L, Giovinazzi S, Forloni M, Boldrini R, Donfrancesco A, Federici V, Giacomini P, Peschle C, Fruci D: Antagomir-17$5 p$ abolishes the growth of therapy-resistant neuroblastoma through p21 and BIM. PLoS One 2008, 3:e2236.

14. Wang Q, Li YC, Wang J, Kong J, Qi Y, Quigg RJ, Li X: miR-17-92 cluster accelerates adipocyte differentiation by negatively regulating tumorsuppressor Rb2/p130. Proc Natl Acad Sci USA 2008, 105:2889-2894.

15. Xiao C, Srinivasan L, Calado DP, Patterson HC, Zhang B, Wang J, Henderson JM, Kutok JL, Rajewsky K: Lymphoproliferative disease and autoimmunity in mice with increased miR-17-92 expression in lymphocytes. Nat Immunol 2008, 9:405-414.

16. Rosenwald A, Wright G, Wiestner A, Chan WC, Connors JM, Campo E, Gascoyne RD, Grogan TM, Muller-Hermelink HK, Smeland EB, Chiorazzi M, Giltnane JM, Hurt EM, Zhao H, Averett L, Henrickson S, Yang L, Powell J, Wilson WH, Jaffe ES, Simon R, Klausner RD, Montserrat E, Bosch F, Greiner TC, Weisenburger DD, Sanger WG, Dave BJ, Lynch JC, Vose J, et al The proliferation gene expression signature is a quantitative integrator of oncogenic events that predicts survival in mantle cell lymphoma. Cancer Cell 2003, 3:185-197.

17. Chu EC, Tarnawski AS: PTEN regulatory functions in tumor suppression and cell biology. Med Sci Monit 2004, 10:RA235-241.

18. Kandasamy K, Srivastava RK: Role of the phosphatidylinositol 3'-kinase/ PTEN/Akt kinase pathway in tumor necrosis factor-related apoptosis- inducing ligand-induced apoptosis in non-small cell lung cancer cells. Cancer Res 2002, 62:4929-4937.

19. Liu JL, Sheng X, Hortobagyi ZK, Mao Z, Gallick GE, Yung WK: Nuclear PTENmediated growth suppression is independent of Akt down-regulation. Mol Cell Biol 2005, 25:6211-6224.

20. Brognard J, Sierecki E, Gao T, Newton AC: PHLPP and a second isoform, PHLPP2, differentially attenuate the amplitude of Akt signaling by regulating distinct Akt isoforms. Mol Cell 2007, 25:917-931.

21. Ramaswamy S, Nakamura N, Vazquez F, Batt DB, Perera S, Roberts TM, Sellers WR: Regulation of G1 progression by the PTEN tumor suppressor protein is linked to inhibition of the phosphatidylinositol 3-kinase/Akt pathway. Proc Natl Acad Sci USA 1999, 96:2110-2115.

doi:10.1186/1748-717X-5-100

Cite this article as: Jiang et al: MicroRNA-17-92 significantly enhances radioresistance in human mantle cell lymphoma cells. Radiation Oncology 2010 5:100.

\section{Submit your next manuscript to BioMed Central and take full advantage of:}

- Convenient online submission

- Thorough peer review

- No space constraints or color figure charges

- Immediate publication on acceptance

- Inclusion in PubMed, CAS, Scopus and Google Scholar

- Research which is freely available for redistribution

Submit your manuscript at www.biomedcentral.com/submit
C BioMed Central 